\title{
EDITORIAL
}

\section{PUBLICACIÓN VÁLIDA}

En cuanto al concepto de publicación válida -de donde deriva la definición de artículo científico-, el Consejo de Editores de Biología (Council of Biology Editors. 1968. Proposed definition of a primary publication. NewsLetter, CBE, November 1968, págs. 1-2) ha llegado al siguiente criterio: una publicación científica primaria aceptable deberá ser la primera revelación que contenga suficiente información para permitir (i) evaluar observaciones, (ii) repetir experimentos y (iii) valorar procesos intelectuales; además, debe ser susceptible a la percepción sensorial, esencialmente permanente, disponible sin restricción a la comunidad científica y asequible para el pesquisaje regular por uno o más de los principales servicios secundarios reconocidos (Applied Science and Technology Index, Computer and Control Abstracts, Electrical and Electronics Abstracts, Engineering Index, etcétera).

Al parecer, la definición podría dar la impresión de ser excesivamente compleja, o al menos rebuscada; pero si se pondera con cuidado cada término se entenderá que una definición aceptable no cabría en menos palabras. Sobre la base de la importancia que tiene para estudiantes, autores, editores y todos aquellos interesados en conocer qué se considera como artículo científico, estimamos necesario analizar esta definición con el propósito de saber su real significado.

El párrafo de referencia se inicia con la frase definida, "Una publicación científica primaria aceptable", pero esta frase es seguida de "la primera revelación", que a su vez se define en el resto del párrafo. Lógicamente, la primera notificación de datos investigativos nuevos ocurre con frecuencia como la presentación oral en determinado evento de carácter científico. Sin embargo, esto implica algo más que la tradicional disertación oral por parte del autor; la primera revelación efectiva se realiza únicamente cuando la notificación adquiere una forma que permite a los demás científicos o especialistas (ya sea ahora o en el futuro) comprender lo que se desea comunicar.

De hecho, la información suficiente deberá presentarse de manera que los usuarios potenciales de los datos puedan evaluar observaciones, repetir experimentos y valorar procesos intelectuales. ¿Se justifican las conclusiones del autor por los datos obtenidos? Entonces, la notificación deberá ser asimismo "susceptible a la percepción sensorial". Ello pudiera parecer una frase difícil, mas en la práctica normal sólo significa el hecho de que la notificación se publique. Esta definición incluye la comunicación no sólo en términos de materiales visuales (revistas, microfilmes, microfichas), sino también quizás en formas no impresas o no visuales. Por ejemplo, una publicación en forma de compact disc, digital video disc, si ésta reúne los requisitos señalados en la definición, podría constituir una publicación efectiva. En el futuro inmediato, es muy posible que la primera notificación sea a través de la entrada de datos por medios computarizados.

Con independencia de la forma de publicación, ésta debe ser esencialmente permanente, disponible sin restricción para la comunidad científica y asequible para los servicios de recuperación de la información. De esto se infiere que las publicaciones tales como cartas noticiosas y órganos institucionales de circulación limitada (materiales que suelen ser de valor por su información y otros rasgos) no podrán servir de repositorios para el conocimiento científico. 
Si se pretendiera ofrecer una definición en términos más simples, pero no más precisos, podría expresarse que un artículo científico es (i) la primera publicación de resultados originales de investigación, (ii) en una forma que le permita al resto de los investigadores repetir los experimentos y evaluar las conclusiones, y (iii) en una revista u otra fuente documental, disponible oportunamente para la comunidad científica. No obstante, a fin de comprender esta definición habría que añadir una advertencia muy importante. En la ciencia moderna -desde el decenio de los 30-, la parte de la definición que se refiere al resto de los investigadores se acepta como la revisión previa del trabajo por parte de especialistas designados (árbitros). Así, por definición, los artículos científicos se publican como material previamente revisado.

Este aspecto acerca de la definición merece destacarse por dos razones. Primero, toda la comunidad científica ha tenido que trabajar durante mucho tiempo con un costoso e ineficiente sistema de comunicación, porque precisamente el sistema (autores, árbitros, editores, etcétera) ha sido incapaz o poco motivado para definir una publicación primaria. Como resultado de ello, mucha literatura se encuentra enterrada en resúmenes de eventos, conferencias sobre informes, documentos gubernamentales, y en folletos o revistas de circulación reducida. Otros trabajos, en igual o similar forma, se publican dos o más veces; con mayor frecuencia es la falta de una definición acerca de qué informes orales, libros y compilaciones son (o deben ser) publicaciones primarias y cuáles no, todo lo cual deriva en redundancia y confusión.

Segundo, un artículo científico es, por definición, un tipo particular de documento que contiene determinados tipos específicos de información. Un artículo científico exige exactamente las mismas cualidades de pensamiento que son necesarias para el resto de la ciencia: lógica, claridad y precisión. Si el recién graduado o el científico novel (e incluso algunos investigadores más avezados) pueden comprender cabalmente el significado de esta definición, la tarea de escribir debiera ser mucho más fácil. La labor fácil es aquella en la que se sabe exactamente qué debe hacerse y en qué orden debe hacerse.

\author{
Comité Editor \\ Universidad de Tarapacá \\ Arica-Chile
}




\section{EDITORIAL}

\section{SCIENTIFIC PUBLICATIONS}

As defined in the November 1968 issue of The Council of Biology Editors (pp.1-2), a reputable primary scientific publication - which has determined the qualities of a scientific article - is a first report containing enough information that (i) allows assessment observations, (ii) repetition of experiments and (iii) intellectual process judgments, and it is available to the scientific community and accredited secondary services such as: Applied Science and Technology Index, Computer and Control Abstracts, Electrical and Electronics Abstracts, Engineering Index, etc., for regular consultation.

This concept may appear excessively complex, but if we reflect about it, we will conclude that an acceptable definition of scientific publication could not be represented with less words.

Because this information is important for students, authors, editors and anyone interested in knowing what is considered to be a scientific publication, it is necessary to analyze this definition, in order to see what it really means.

From the paragraph above, one can infer that an acceptable scientific article is preceded by a first account, eg., an oral presentation in a professional conference, whose form allows other scientists and specialists to understand what is being communicated.

As stated before, the information must be presented in such a way that the audience is able to assess the observations, as well as repeat the experiments and judge intellectual processes. The essential question being: does the data presented support the author's conclusions? This question can only be answered if the first account is published as a journal article, a microfilm or microfiche, or is transmitted using other means such as audio cassettes or virtual texts.

Regardless of the publication format, the account must be permanently available to the scientific community without restrictions. Materials of limited availability, such as newsletters and institutional publications, should not be considered as repositories of scientific knowledge.

If one would want to summarize what has been discussed before, in simpler but less accurate terms, we could say that a scientific article is a work that (i) is the published result of original research, (ii) allows scientists to repeat the experiments and assess its conclusions, and (iii) it is permanently available to the scientific community. 
This latter aspect of the definition must be emphasized because of two main reasons. On the one hand, because the scientific community has worked diligently in trying to improve the inefficient performance of the peer review system, which has not been successful in defining primary scientific publications. This inefficacy resulting in much of the literature buried in summaries of events, conference reports, and magazine articles of limited circulation, and works published in more than one journal, due to redundancy and confusion, or because of authors' unethical stand.

On the other hand, by definition, a scientific article must contain information that stems from the same thinking processes found in science, like transparency and precision.

If the young graduate, the new scientist and even the seasoned scholar understand the meaning of the concept of a scientific article, writing should be much easier, as the easiest task is the one where we know what to do and in what order to work.

\section{Editor Committee Universidad de Tarapacá Arica-Chile}

